P-ISSN 2580 - 7781

E-ISSN 2615 - 3238

\title{
RANCANG BANGUN SISTEM INFORMASI E-COMMERCE DALAM PENJUALAN HARDWARE KOMPUTER BERBASIS WEBSITE
}

\section{DESIGN AND BUILD E-COMMERCE INFORMATION SYSTEMS IN WEBSITE BASED COMPUTER HARDWARE SALES}

\author{
Walim $^{1)}$, Suhardi ${ }^{2)}$ \\ Program Studi Sistem Informasi/Program Sistem Informasi Akuntansi \\ Universitas Bina Sarana Informatika \\ e-mail: ${ }^{1}$ walim.wam@bsi.ac.id
}

\begin{abstract}
ABSTRAK
Di era globalisasi sekarang ini yang sudah memasuki era 4.0 sehingga perkembangan serta kemajuan teknologi semakin pesat, dan tidak menutup kemungkinan juga persaingan bisnis atau usaha semakin ketat di bidang apapun salah satunya di bidang $e$ commerce. Maka pemanfaatan teknologi yang begitu mutakhir sekarang ini di perlukan untuk mengatasi hal tersebut sehingga bisnis atau usaha kita tidak ketinggalan jaman. Untuk itu dalam menjawab tantangan-tantangan dalam era globalisasi atau 4.0 maka dalam hal ini perlu merancang dan membuat suatu web yaitu website e-commerce yang berisi informasi dan penjualan secara online. Adapun penelitian ini mengambil contoh objek penjualan hardware computer dengan berbasis web, disamping itu juga untuk membantu usaha yang bergerak dibidang penjualan hardware, pemograman website ecommerce penjualan hardware komputer ini dibuat dengan menggunakan macromedia dreamweavear MX2004, MySQL dan menggunakan metode waterfall karena dengan metode ini lebih mudah dalam merancang website. Tujuan penelitian ini membuat website terutama web e-commerce tidak lain bertujuan untuk menyampaikan informasi kepada masyarakat secara cepat, sehingga informasi mudah didapat dan mempermudah masyarakat dalam melakukan pembelian hardware komputer.
\end{abstract}

Kata kunci: E-commerce, Hardware, Website

\begin{abstract}
In the current era of globalization which has entered the 4.0 era so that the development and advancement of technology is rapidly increasing, and it does not rule out the possibility of business competition or even tougher business in any field one of which is in the field of e-commerce. So the use of technology that is so cutting-edge now is needed to overcome this so that our business or business is not outdated. For that reason, in responding to challenges in the globalization era or 4.0, in this case it is necessary to design and create a website that is an e-commerce website that contains information and online sales. The research takes the example of computer hardware sales objects with web-based, besides that also to help businesses engaged in hardware sales, programming of e-commerce websites selling computer hardware is made using Macromedia Dreamweavear MX2004, MySQL and using the waterfall method because with this method easier in designing websites. The purpose of this research is to create a website, especially e-commerce web, which aims to convey information to the public quickly, so that information is easily obtained and makes it easier for people to make purchases of computer hardware.
\end{abstract}

Keywords: E-commerce, Hardware, Website 
P-ISSN 2580 - 7781

E-ISSN 2615 - 3238

\section{PENDAHULUAN}

Kemajuan teknologi informasi yang pesat serta potensi pemanfaatannya yang luas,membuka peluang bagi pengaksesan, pengelolaan, dan pendayagunaan informasi dalam volume yang besar secara cepat dan akurat. Arus globalisasi merupakan realita yang harus di hadapi oleh semua orang, dimana kita dituntut untuk bergerak cepat pada semua aktifitas(Sukatmi, 2018). Begitu juga dengan sebuah perusahaan, bahkan instansi pemerintah. Dengan adanya sebuah sistem yang terkomputerisasi diharapkan akan memberikan kemudahan untuk mendapatkan informasi yang cepat dan akurat. Teknologi Komputer juga digunakan untuk penjualan, salah satu fasilitas internet untuk melakukan penjualan onlineyang dikenal dengan istilah e-commerce(Susandi \& Sukisno, 2017). Dewasa ini banyak perusahaan dagang terkemuka yang mempunyai website berbasis e-commerce untuk mempromosikan produk dan jasa mereka karena dengan adanya e-commerce jalannya sebuah kegiatan perniagaan dapat dilakukan dari rumah tanpa harus mengeluarkan biaya dan waktu lebih. Maka dengan adanya e-commerceini dimanfaatkan oleh penulis untuk memperkenalkan dan mempromosikan macam-macam hardware komputer yang sangat dibutukan oleh banyak pengguna komputer apalagi di jaman modern sekarang ini begitu banyak sekali para pengguna komputer yang kesulitan mencari macam-macam hardware komputer yang dibutuhkan apalagi ketika laptop atau komputernya mengalami kerusakan hardware seperti kerusakan keyboard pasti sangat membantu dengan adanya toko hardwareonline yang akan menjual bermacammacam komponen komputer atau hardware dan juga penjualan barang tidak hanya mengandalkan kelebihan asertif dari penjual atau salesman yang dimiliki perusahaan dagang baik barang atau jasa (Widyastuti, Bisri, \& Suhardi, 2020)

Terlebih powerbyte memiliki toko offline di daerah cikampek kabupaten Karawang, yaitu kabupaten dengan kepadatan penduduk yang cukup tinggi mencapai 2.273.000 jiwa (Suhardi, Widyastuti, Bisri, \& Prabowo, 2019) sehngga sangat berpotensi untuk bisnis ritel alat-alat komputer dan jasa perbaikan perangkat komputer. Hal ini juga perlu dijadikan faktor penyangga bisnis secara umum. Namun powerbyte secara spesifik sudah menargetkan segmentasi 
P-ISSN 2580 - 7781

E-ISSN 2615 - 3238

bisnisnya yaitu pelanggan dengan tingkat penggunaan gadget tinggi seperti pegawai kantor dan pelajar atau mahasiswa, hal ini sesuai dengan artikel penelitian tentang pengelompokan data pelanggan potensial, bahwa pelanggan akan dengan sendirinya mengelompokkan pada klaster-klaster sesuai dengan minat dan kemampuan daya beli mereka secara alamiah baik disadari atau tidak (Gata, Basri, Puspitawati, \& Hidayat, 2019) dan tidak hanya sebagai kebutuhan saja namun lebih dari itu pelanggan juga dapat mengelompokkan diri mengikuti gaya hidup mereka masing masing (Suhardi, 2019).

Prospektif ini sangat menjanjikan karena banyak sekali para pengguna komputer atau sejenisnya di dunia ini bahkan anak SD sekalipun sudah ada yang mempelajari komputer. Tetapi terkendalanya jarak ketika mau membeli komponen-komponen hardware komputer.

Dari permasalahan yang telah penulis paparkan diatas maka dalam penyusunan penelitian ini penulis mengambil judul "Rancang Bangun Sistem Informasi e-commerce Dalam Penjualan Hardware Komputer Berbasis Web” .

\section{METODE PENELETIAN}

Adapun metode penelitian yang penulis gunakan antara lian mengunakan model SDLC air terjun (waterfall) sering juga disebut model sekuensial linier (sequential linier) atau alur hidup klasik (classic life cycle) (Shalahuddin, n.d.) metode penelitian yang penulis gunakan antara lain:

\section{Analisis Kebutuhan}

Analisis kebutuhan aplikasi dilakukan untuk mengetahui kebutuhan pelanggan terhadap program informasi yang berbasis web agar mempermudah informasi dan transaksi pada toko hardware online tersebut.

2. Perancangan Sistem dan Perangkat Lunak

Proses pemograman website e-commerce ini di fokuskan pada empat atribut, yaitu struktur data, representasi antarmuka, arsitektur perangkat lunak, dan interaksi antar objek di dalam kelas. 
P-ISSN 2580 - 7781

E-ISSN 2615 - 3238

3. Implemantasi

Pada tahap ini perancangaan perangkat lunak direalisasikan sebagai serangkaian program atau unit program, dengan menggunakan Macromedia Dreamweaver MX 2004.

Teknik pengumpulan data yang digunakan dalam penelitian ini adalah :

1. Observasi

Observasi menurut Sugiyono (Sugiyono, 2016)meliputi “ suatu proses yang kompleks, suatu proses yang tersusun dari pembagai proses biologis dan psikologis". Dalam hal ini Penulis telah melakukan observasi langsung dengan cara mengunjungi ke toko-toko komputer yang ada di Karawang atau mengunjungi situs-situs atau websiteberbasis e-commerce untuk mengetahui cara kerja sebuah situs e-commerce.

2. Wawancara

Dalam memperkuat penelitian ini penulis mewawancarai bapa Alif selaku pemilik usaha powerbyite computer usaha yang bergreak di bidang perangkatperangkatcomputer dan servis.

\section{Studi Pustaka}

Menurut Nazir (Nazir, 2011) meliputi "memperoleh informasi dari penelitian terdahulu harus dikerjakan, tanpa memperdulikan apakah sebuah penelitian menggunakan data primer atau data sekunder". Dan hal ini juga dilakukan untuk mendapatkan data skunder yang akan digunakan sebagai landasan perbandingan antara teori dengan prakteknya di lapangan. Data skunder melalui metode ini diperoleh dengan cara mengambil informasi-informasi penting mengenai permasalahan yang dibahas dengan jelas dari buku-buku referensi, atau browsing di internet (website), Jurnal dan literatur-literatur yang berkaitan dengan $E$ - 


\section{P-ISSN 2580 - 7781}

E-ISSN 2615 - 3238

commerce.

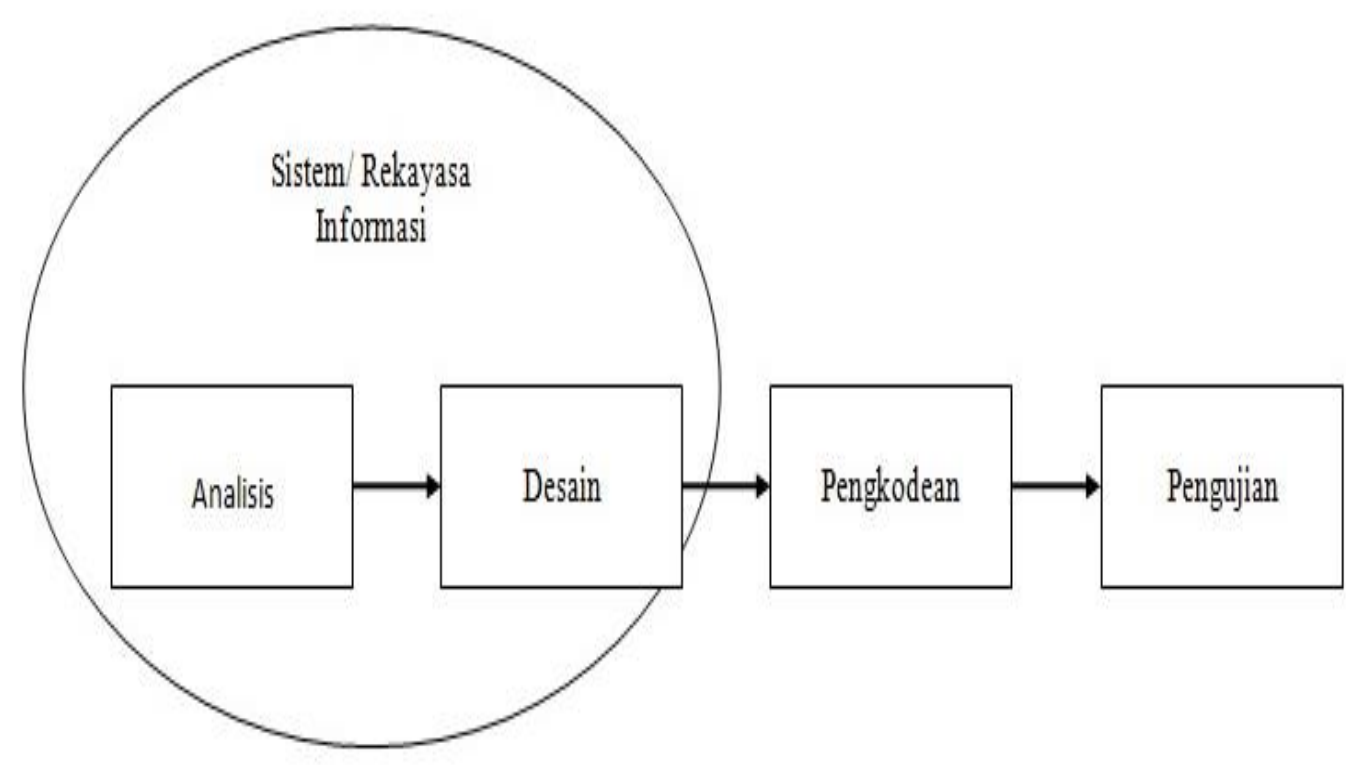

Gambar 1 : Diagram waterffal

Sumber: (Sukamto \& Shalahuddin, 2014)

a. Analisis kebutuhan perangkat lunak

Banyaknya pengguna komputer sehingga kebutuhan akan hardware begitu besar, sehingga banyak sekali orang-orang yang mencari cepat apalagi ketika salah satu bagian yang terpenting komputer rusak contohnya salah satu hardware yaitu hardisk maka para pengguna komputer ingin cepat-cepat mencari hardisk tersebut.

Tahap selanjutnya adalah mengidentifikasi kebutuhan sistem yang akan dibuat atau dirancang. Perancangan sistem yang akan dibuat harus memiliki elemen yang mendukung efektifitas sistem yang akan di implementasikan.

b. Desain

Desain merupakan sebuah prototyipe untuk merancang sebuah program sesuai dengan kebutuhan.

c. Pembuatan Kode Program

Setelah proses pembuatan desain lanjut ke pembuatak pengkodean atau merealisasikan dalam program website e-commerce toko hardware secara online. 
P-ISSN 2580 - 7781

E-ISSN 2615 - 3238

d. Pengujian

Pengujianadalah tahapan terakhir dimana untuk menguji suatu program $e$ commerce toko hardware layak atau tidaknya, untuk pengujian sendiri dilakukan menggunakan blackbook testing.

\section{HASIL DAN PEMBAHASAN}

1. Analisa Kebutuhan Sistem

Analisa kebutruhan sistem di bagi dengan beberapa tahap, sistem informasi yang dibuat meliputi hal berikut:

a. Sistem informasi penjualan hardware laptop dilengkapi dengan fasilitas keamanan (login dan password) bagi pengguna seperti web administrator dan user yang akan berperan sebagai pengguna atau member

b. Sistem dapat mengelola data barang dan menjalankan lagi data transaksi

c. Sistem dapat memudahkan proses pengolahan data transaksi.

d. Sistem dapat menyediakan laman konfirmasi untuk memudahkan informasi pembayaran.

e. Dengan system informasi admin dapat menampilkan informasi pelanggan yang melakukan pembelian.

f. Dengan sistem, admin dapat menampilkan informasi penjualan secara online.

g. Dengan sistem, admin dapat menampilkan informasi jumlah dan spesifikasi barang.

h. Sistem dapat menampilkan, merubah dan menghapus data barang, data pelanggan, buku tamu, data konfirmasi, data pesanan.

Analisa kebutuhan pengguna merupakan tahapan penting dalam membangun sebuah sistem. Spesifikasi mengenai semua kebutuhan yang diinginkan oleh pengguna dilakukan pada tahap ini. Hasil dari analisa kebutuhan pengguna ini digunakan untuk membangun kerangka sistem agar sesuai dengan harapan pengguna.

Adapun spesifikasi kebutuhan pengguna yang akan diterapkan pada sistem ini berdasarkan masing-masing pengguna adalah sebagai berikut: 
P-ISSN 2580 - 7781

E-ISSN 2615 - 3238

a. Web Administrator

1. Web Administrator dapat mengelola data customer

2. Mencetak laporan penjualan

3. Melihat daftar transaksi dari customer

4. Mengelola testimonial

5. Mengelola data buku tamu

\section{b.Customer}

1. Customer dapat mendaftarkandiri sebagai pelanggan.

2. Dapat membeli produk secara mudah

3. Mengisi keranjang belanja

4. Disediakan form untuk login.

c. Pengunjung

1. Pengunjung dapat melihat seluruh content atau isi dari front-end website.

2. Pengunjung dapat mengisi testimonial

3. Pengunjung dapat mengisi buku tamu

4. Pengunjung dapat mendaftar menjadi seorang member.

2. Desain

Rancangan Antar Muka

1. Halaman Home

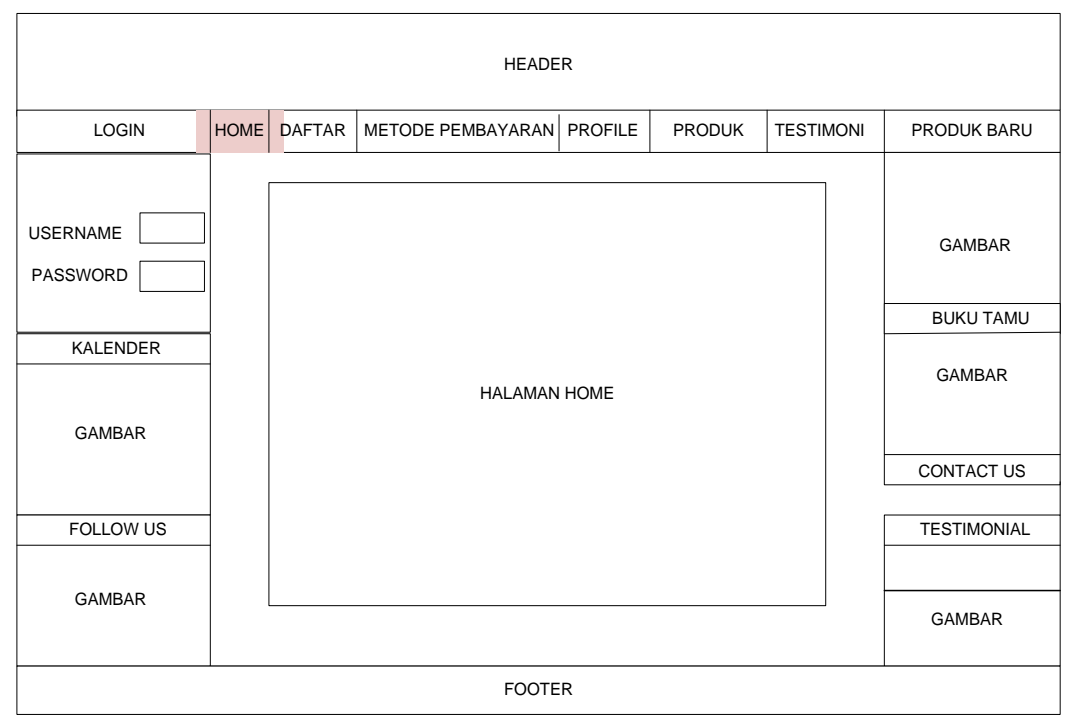

Gambar 2 : Halaman Home 


\section{P-ISSN 2580 - 7781}

E-ISSN 2615 - 3238

2. Halaman Daftar

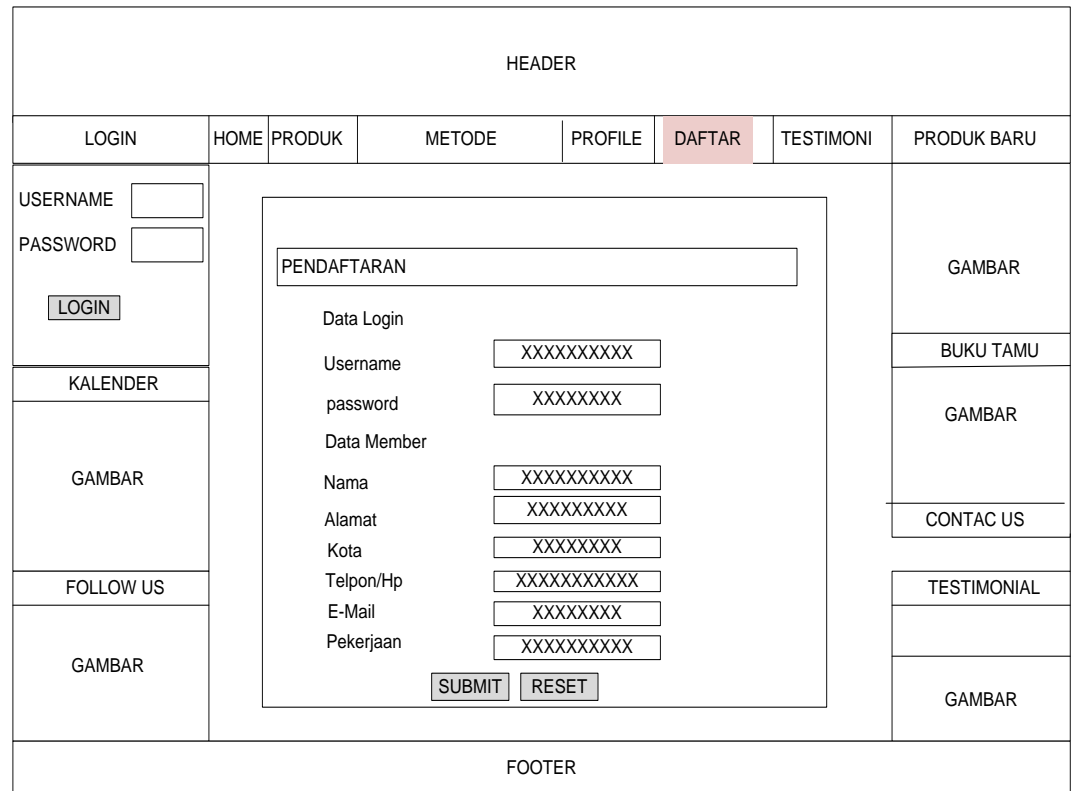

Gambar 3: Halaman Daftar

\section{Halaman Login}

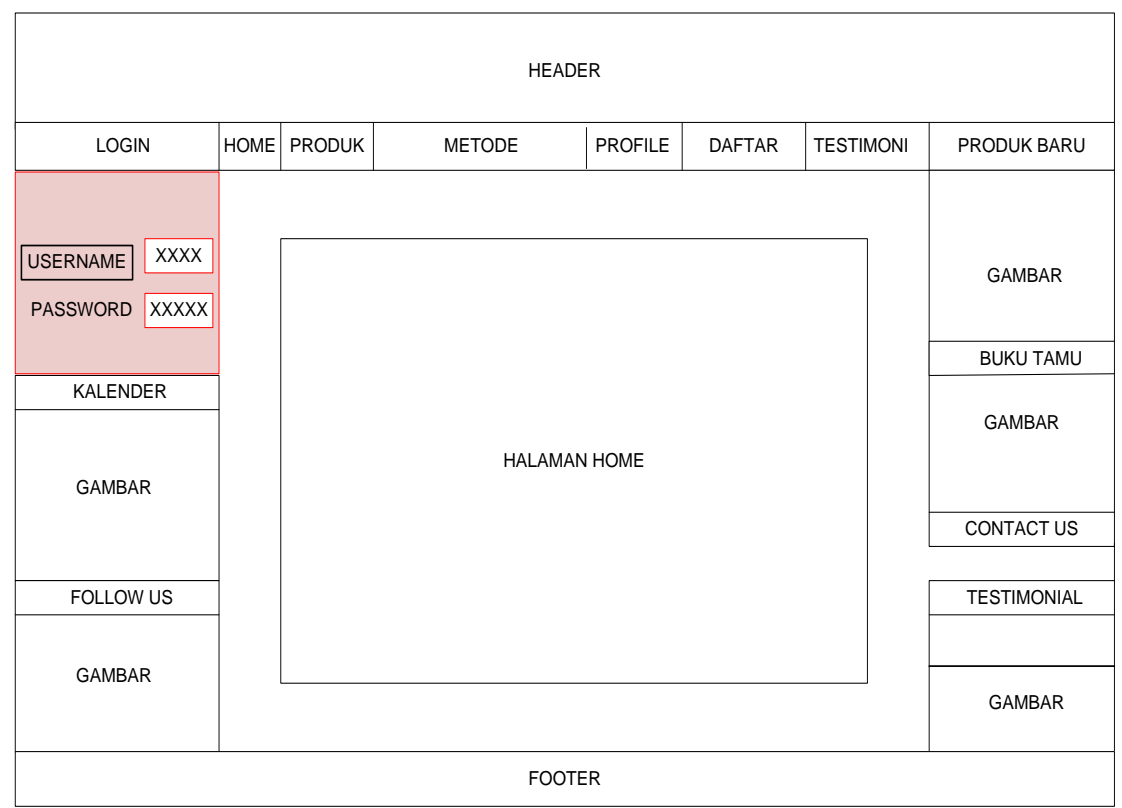

Gambar 4: Halaman Login 


\section{P-ISSN 2580 - 7781}

E-ISSN 2615 - 3238

4. Halaman Keranjang Belanja

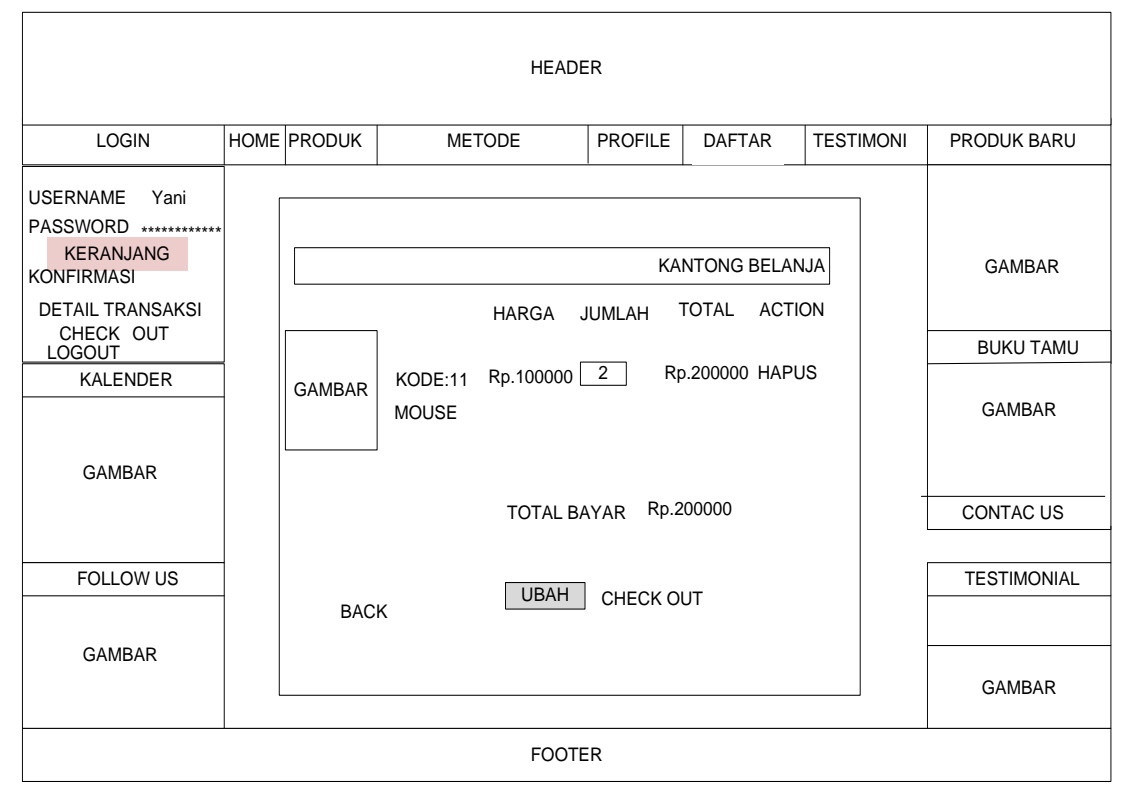

Gambar 5: Halaman Keranjang Belanja 
P-ISSN 2580 - 7781

E-ISSN 2615 - 3238

\section{Entity Relationship Diagram}

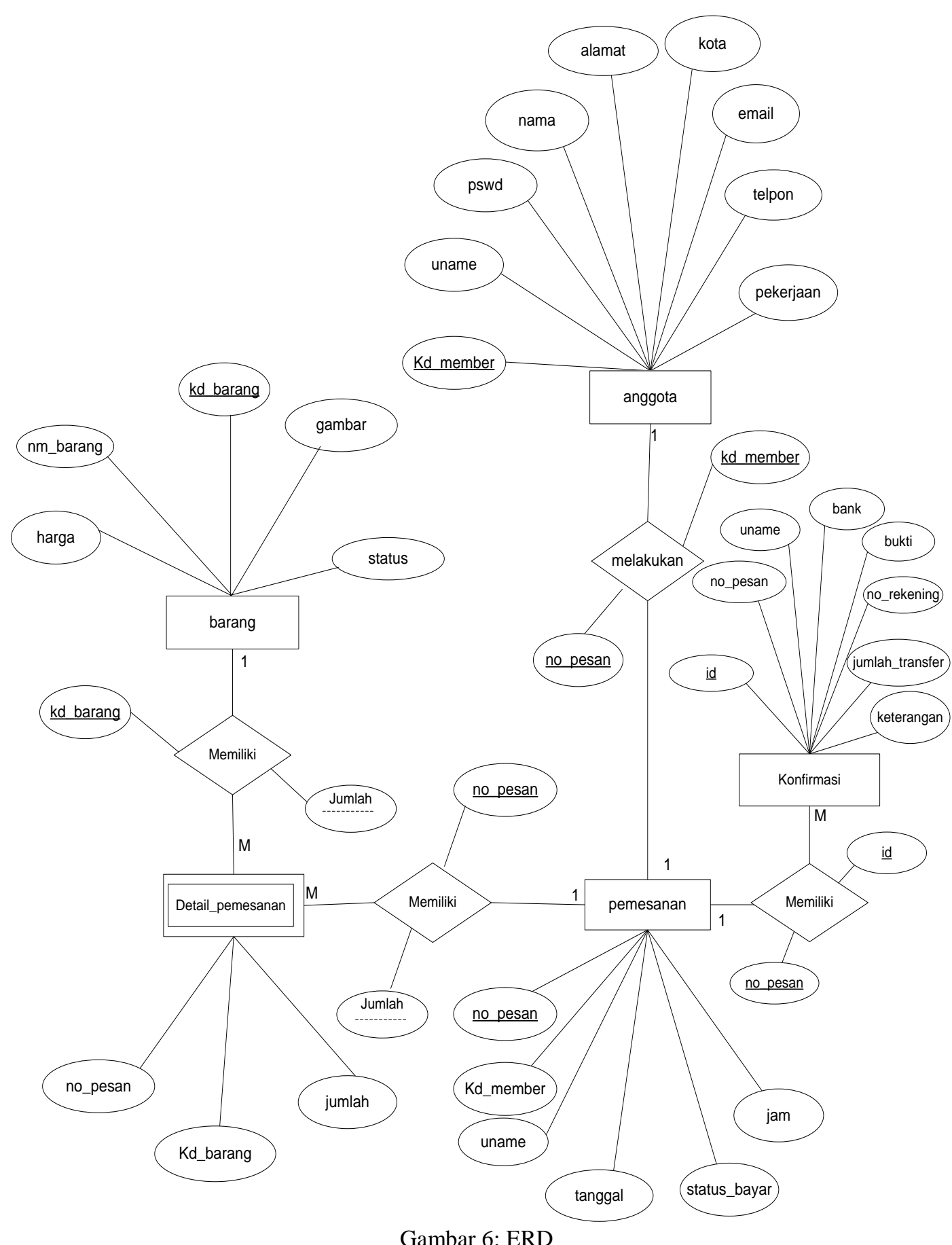




\section{P-ISSN $2580-7781$}

E-ISSN 2615 - 3238

6. LRS

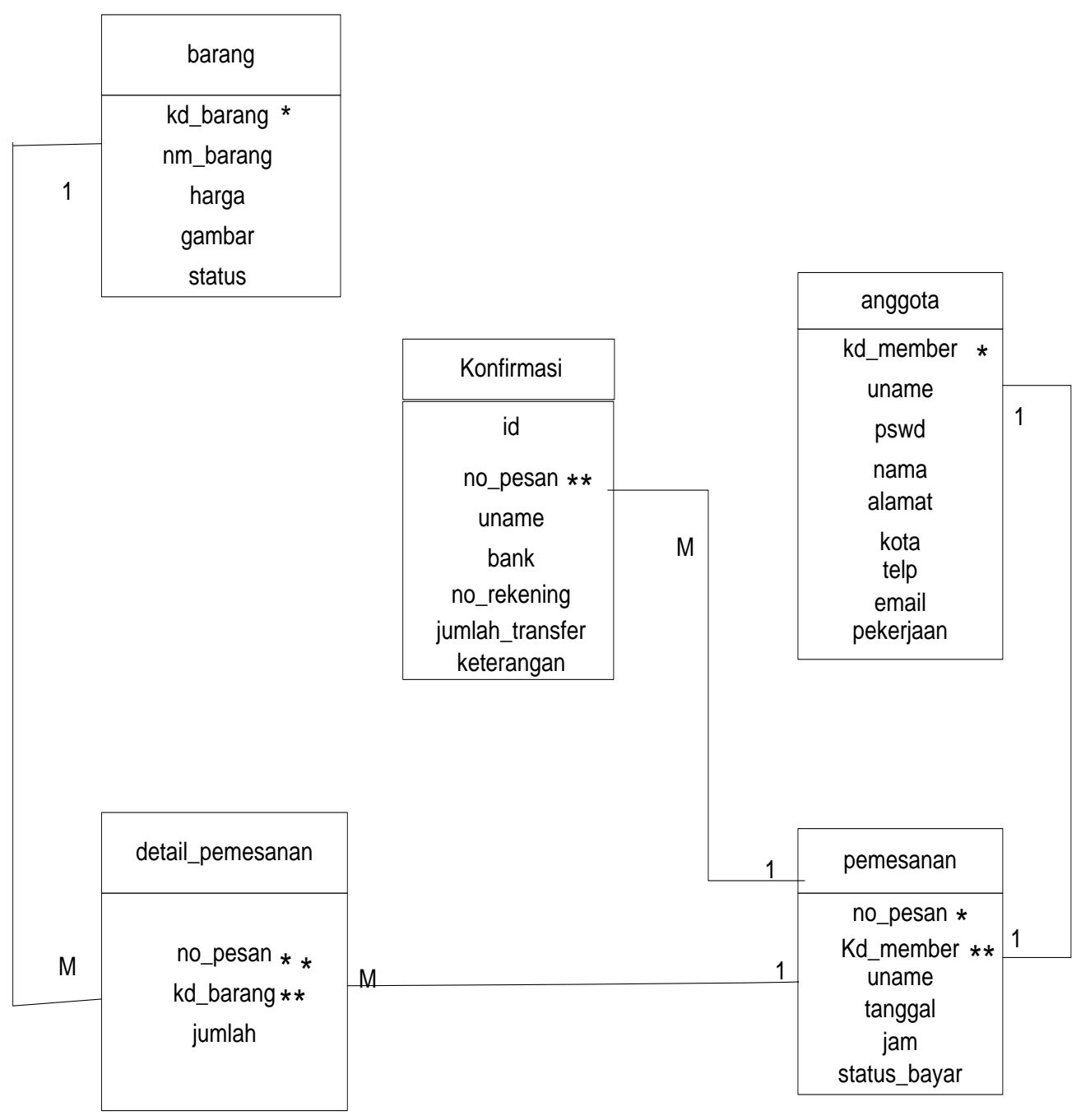

Gambar 7: LRS

7. Struktur Navigasi Admin

Struktur navigasi website digunakan untuk menggambarkan secara garis besar isi dari seluruh website dan menggambarkan bagaimana hubungan antara isi-isi tersebut 


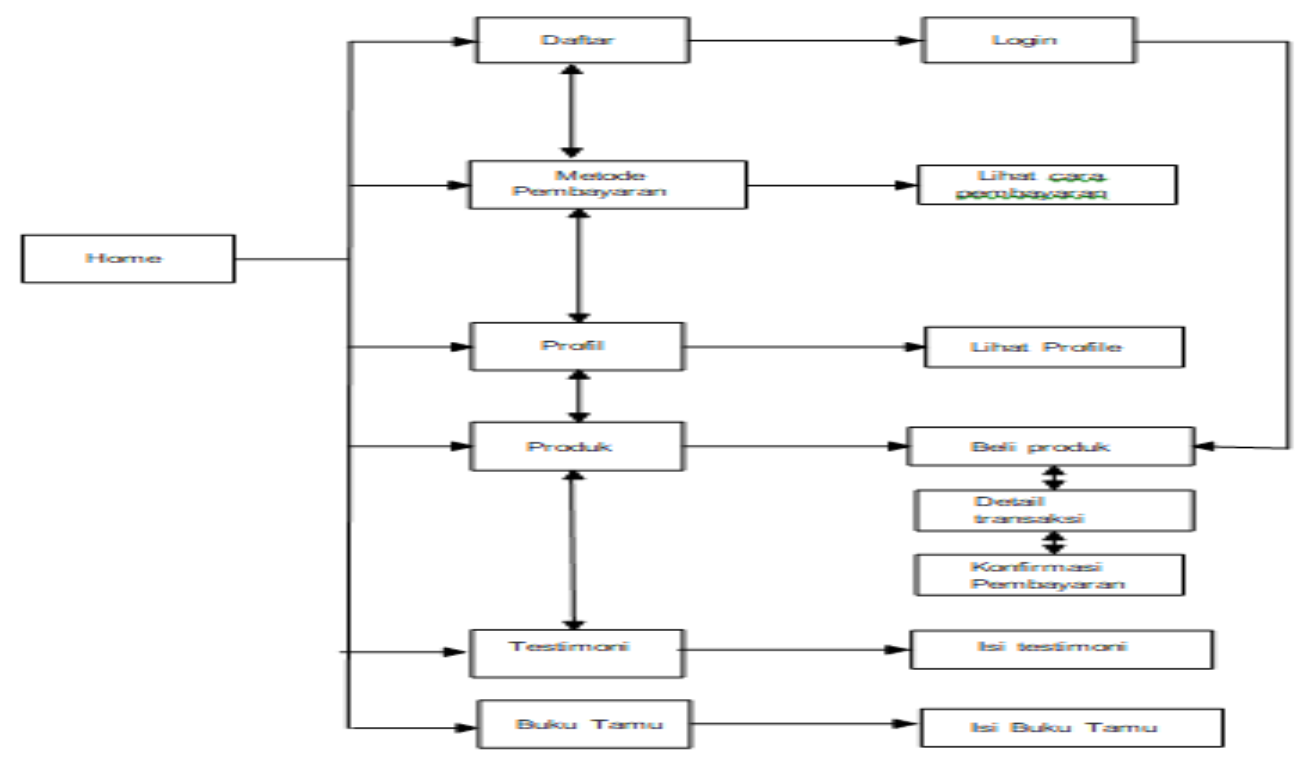

Gambar 8: Diagram Struktur Navigasi

b. Spesifikasi File

Database adalah sekumpulan data yang saling berkaitan satu sama lain, terpusat dan terorganisir sehingga dapat dimanfaatkan dengan cepat dan mudah untuk berbagai macam kebutuhan pengolahan data. Program web yang penulis buat mempunyai database yang berfungsi untuk menyimpan semua data dari pengunjung web serta dari admin. Dalam pembuatan web ini penulis disini membuat database dengan beberapa tabel, adapun spesifikasi file-file tersebut antara lain:

\section{FileAdmin}

Nama File

Akronim

Fungsi

Tipe

Akses File

Media

Panjang Record

Kunci Field
: File Admin

: Login

: Untuk masuk kehalaman utama Home

: File Master

: Random

: Hardisk

: 60 Karakter

: id_user 
Tabel 1 : Spesifikasi File Admin

\begin{tabular}{|c|c|c|c|c|c|}
\hline $\mathrm{M}$ & Elomen Dats & Alyonim & Tipe & 7arian: & Keterngan \\
\hline 1 & Wangm: & Distule siming & Wrrhil & 30 & Primp $\mathrm{KV}$ \\
\hline 2 & Pasud & Powd admin & Vorhy & 30 & \\
\hline
\end{tabular}

2. File Barang

Nama File

: File Barang

Akronim

: Barang

Fungsi

: Untukmenyimpan data barang

Tipe

: File Master

Akses File

: Random

Media

: Hardisk

Panjang Record

: 146 Karakter

Kunci Field

: kd_barang 
P-ISSN 2580 - 7781

E-ISSN 2615 - 3238

Tabel 2: Spesifikasi File Barang

\begin{tabular}{|l|l|l|l|l|l|}
\hline No & Elemen Data & Alronim & Tipe & Parjang & Keterangan \\
\hline 1 & Kode Barang & kd_barang & Fut & 5 & Primary Key \\
\hline 2 & Nama Barang & nm_barang & Varchar & 50 & \\
\hline 3 & Harga Barang & Harga & Vut & 11 & \\
\hline 4 & Gambar Barang & Grmbar & Varchar & 50 & \\
& & & & & \\
\hline 5 & Status Barang & Status & Varchar & 30 & \\
\hline
\end{tabular}

c. User Interface

1. Halaman LoginAdmin

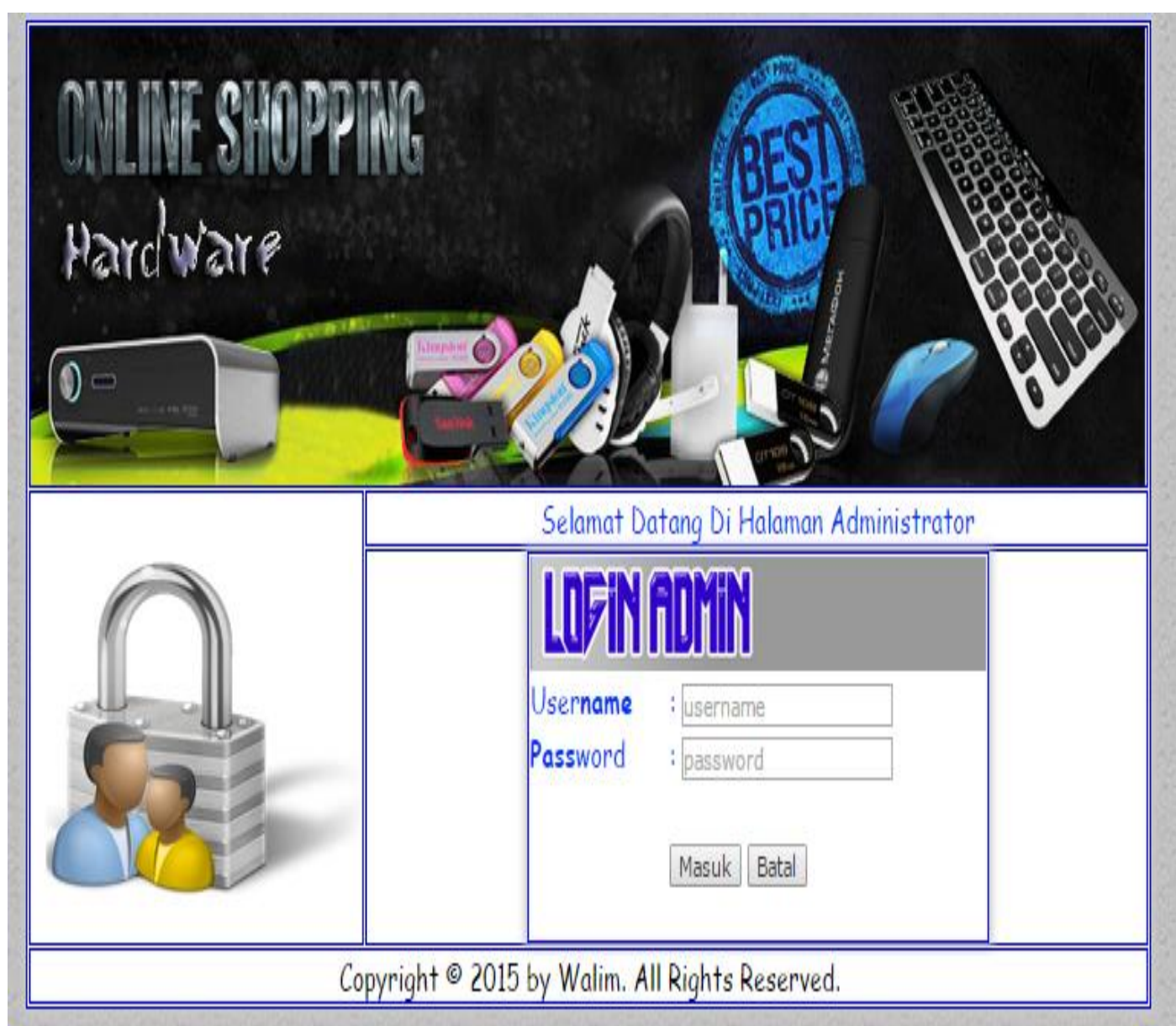

Gambar 9: User Interface Login Admin 
P-ISSN 2580 - 7781

E-ISSN 2615 - 3238

2. Halaman Home Admin

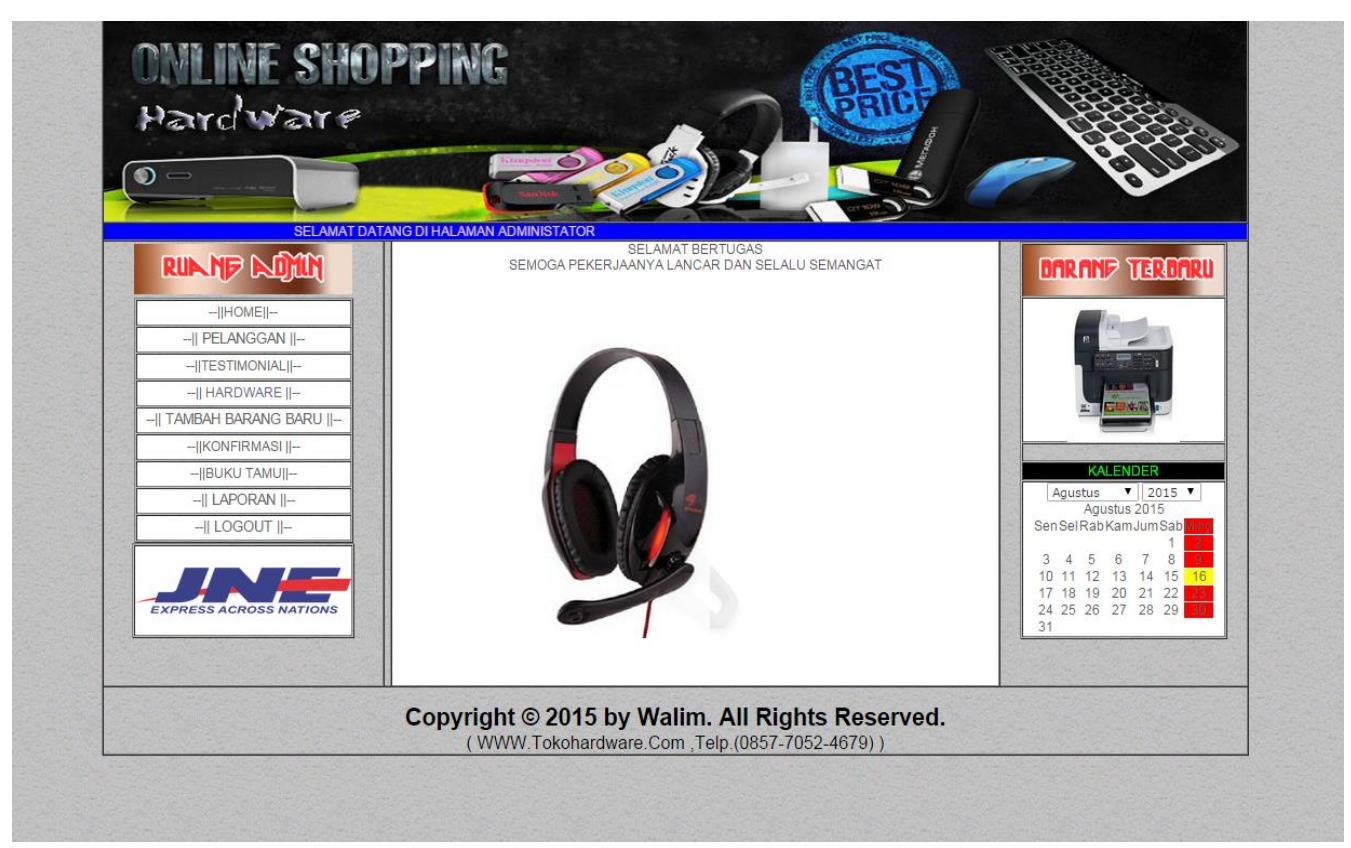

Gambar 10: User Interface Home Admin

3. Halaman Hardware Admin

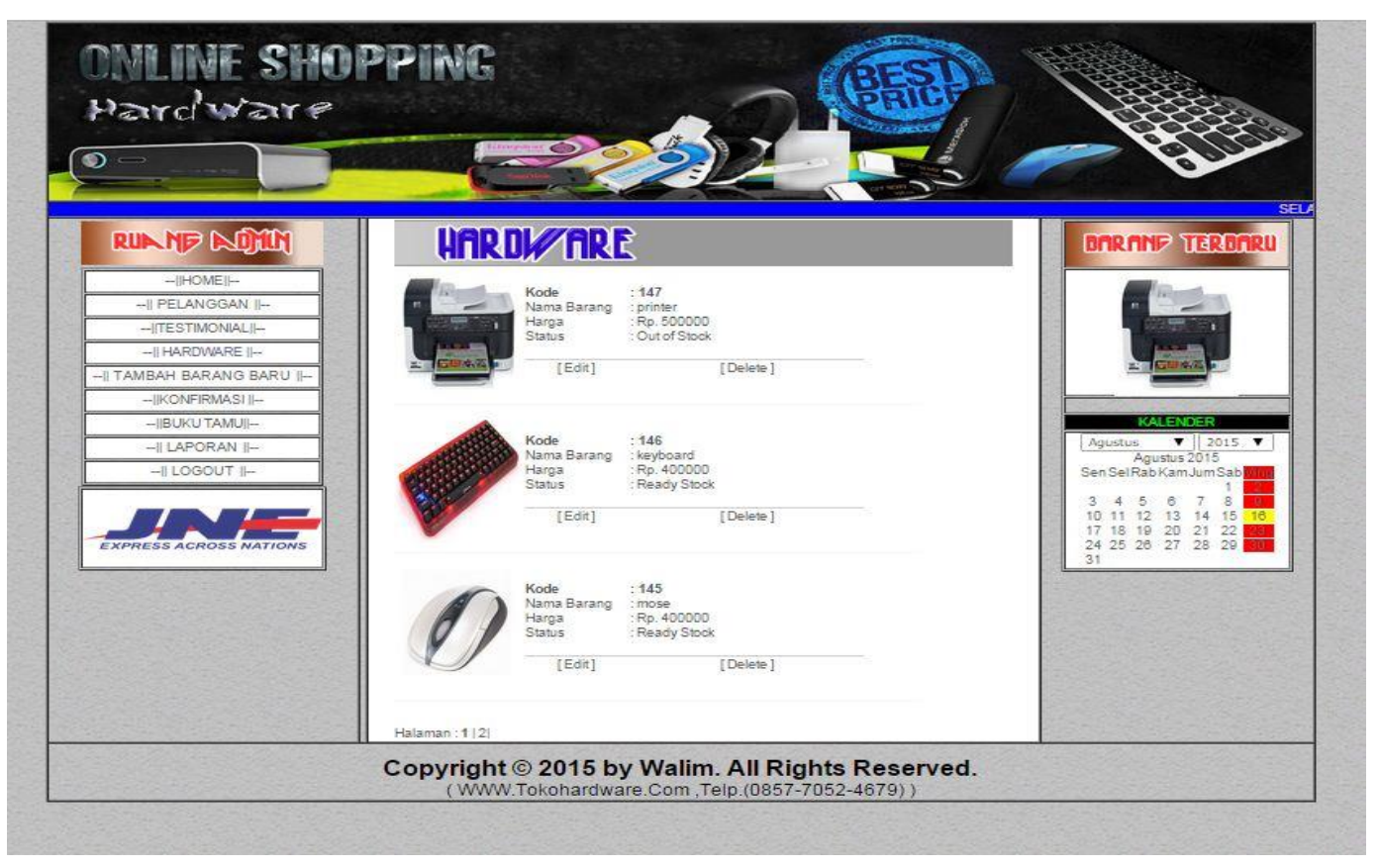

Gambar 11: User Interface Hardware Admin 
P-ISSN 2580 - 7781

E-ISSN 2615 - 3238

4. Halaman Konfirmasi Admin

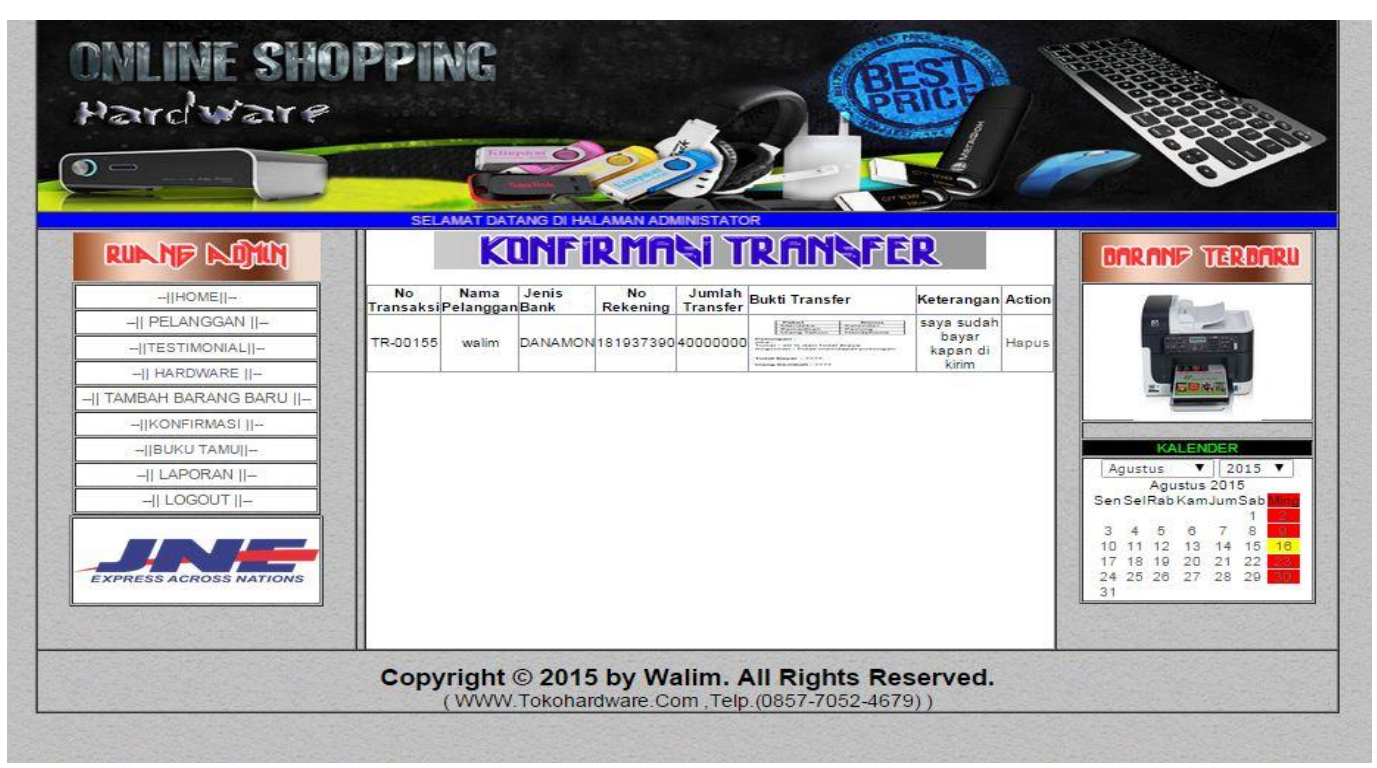

Gambar 12: User Interface Konfirmasi Admin

5. Halaman Index User

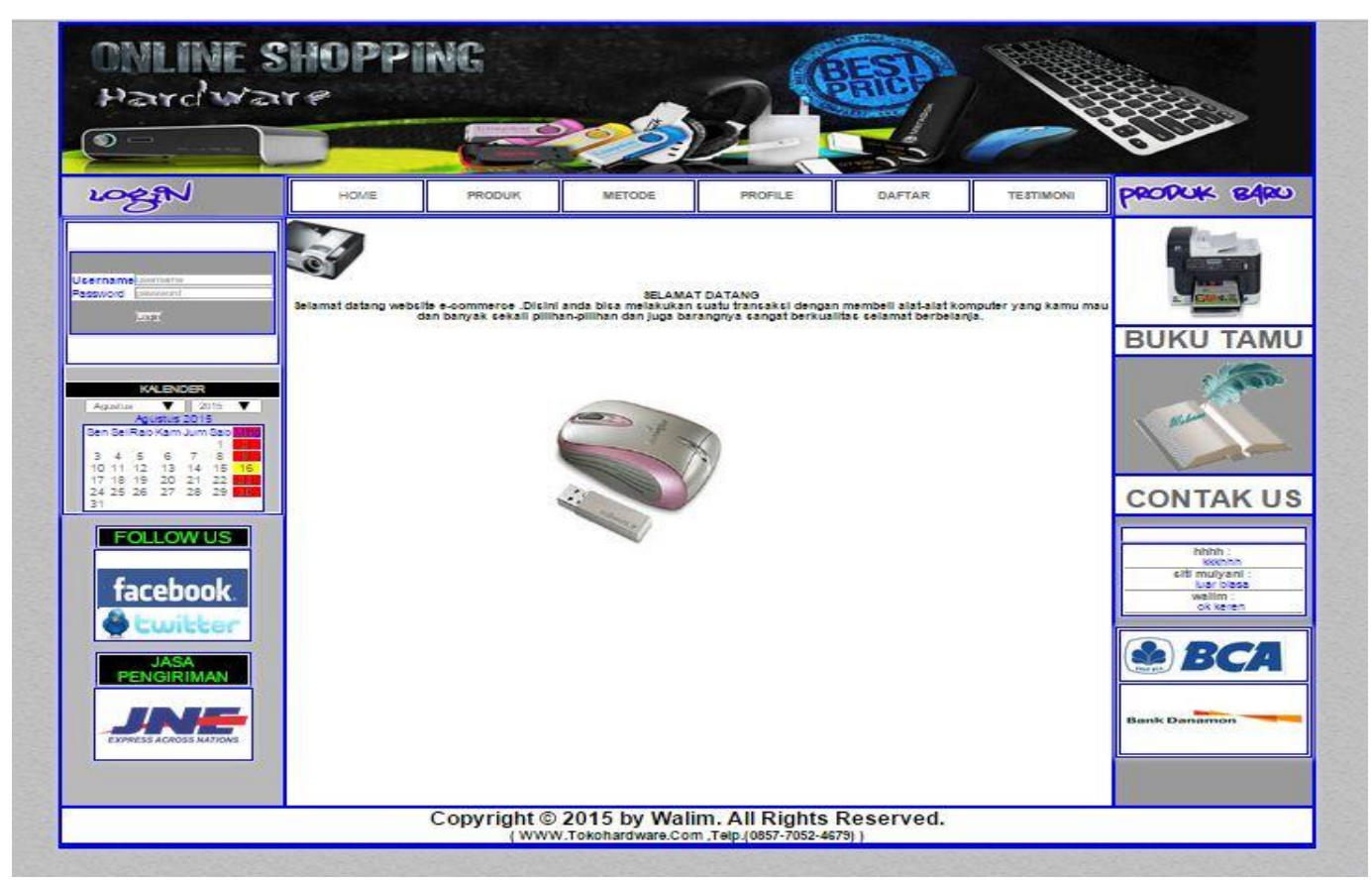

Gambar 13: User Interface Index User 
P-ISSN 2580 - 7781

E-ISSN 2615 - 3238

6. Halaman Produk User

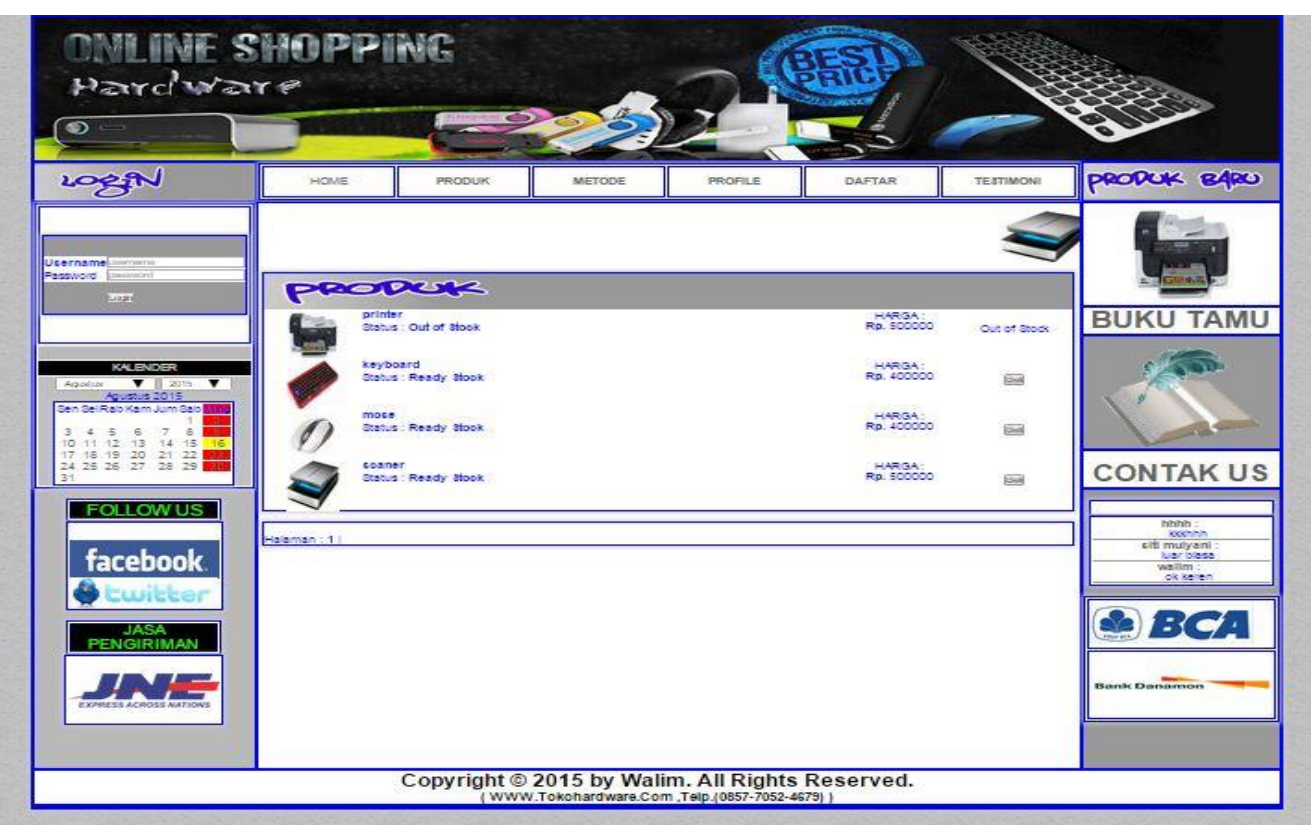

Gambar 14: User Interface Produk User

7. HalamanKeranjang BelanjaUser

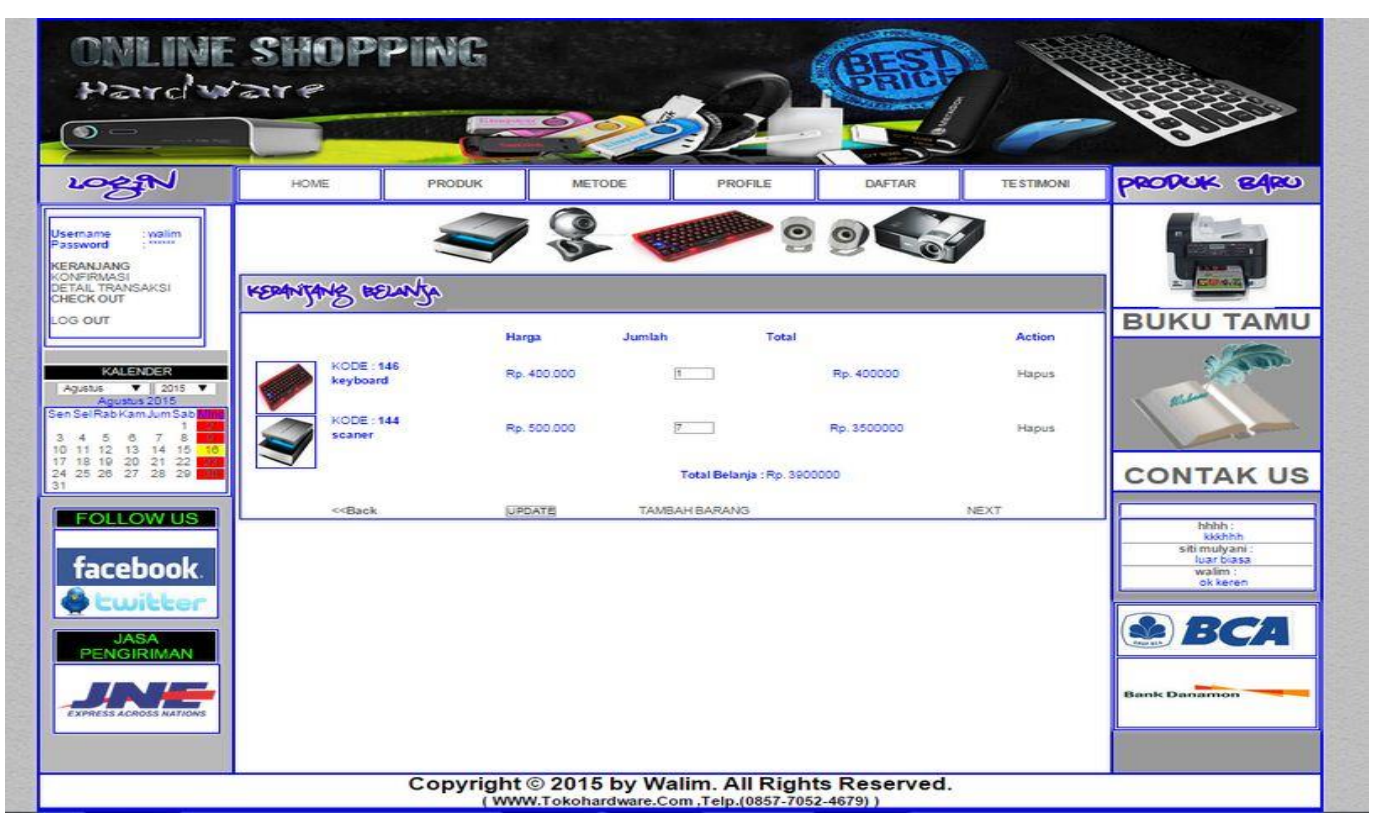

Gambar 15: User Interface Keranjang Belanja User 
P-ISSN 2580 - 7781

E-ISSN 2615 - 3238

8. Halaman Detail Transaksi

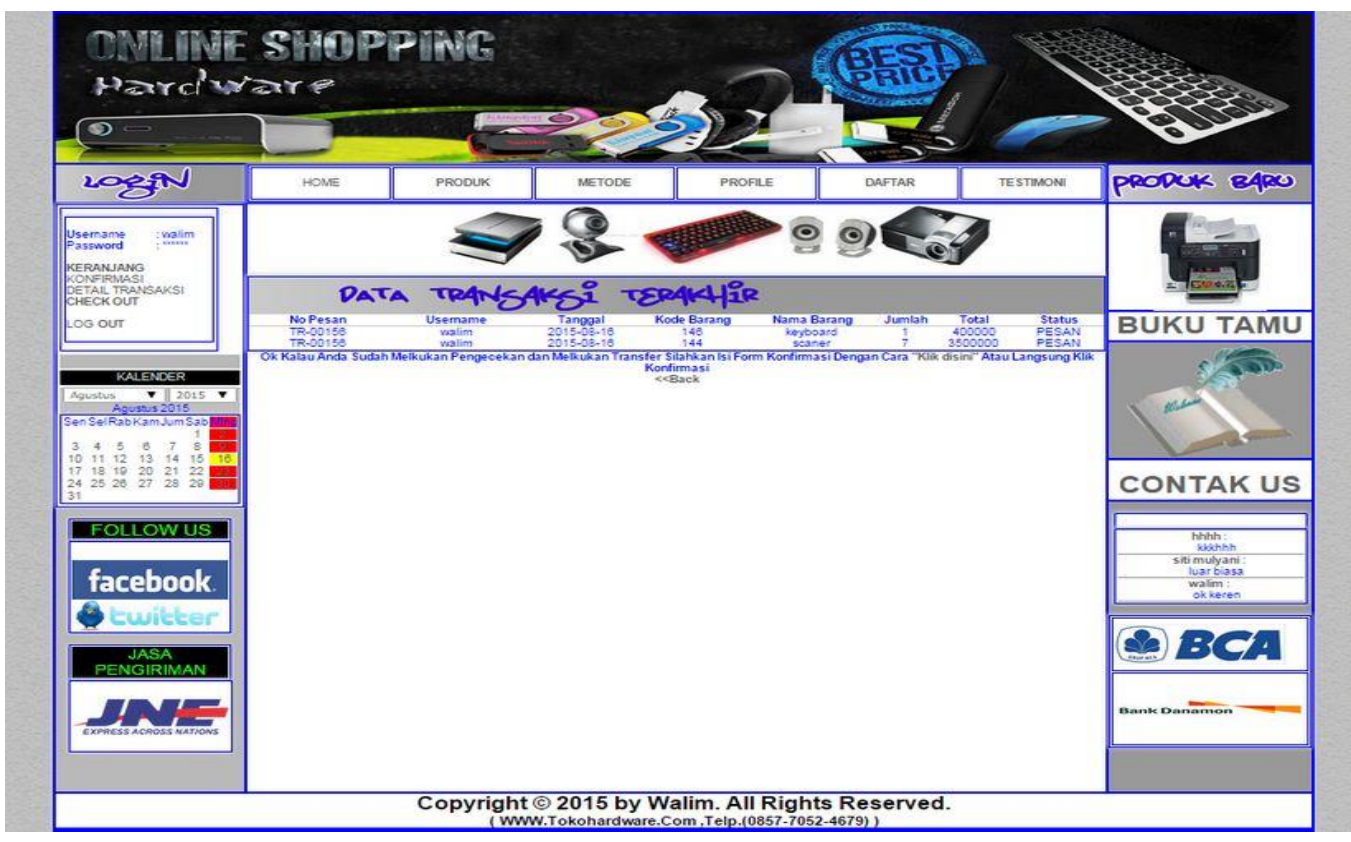

Gambar 16: User Detail Transaksi User

\section{Software Architecture}

\section{Component Diagram}

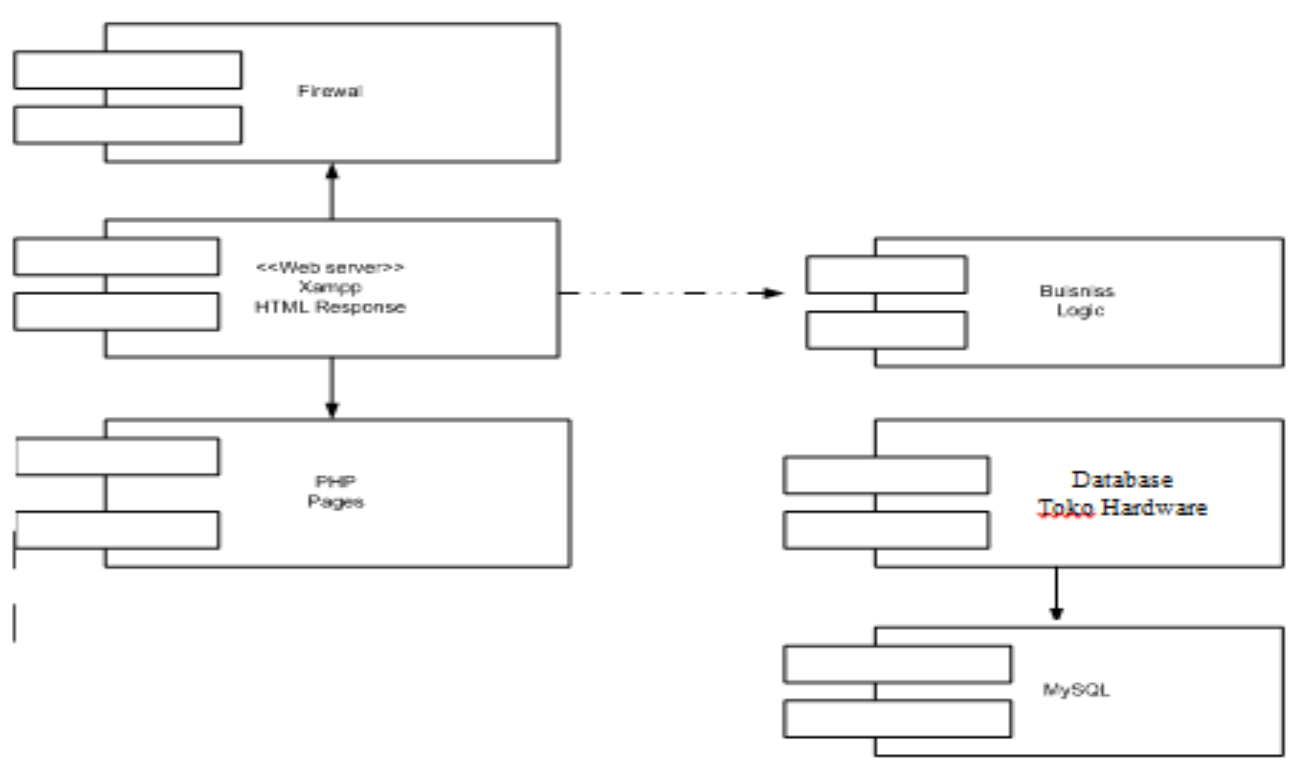

Gambar 17: Component Diagram 
P-ISSN 2580 - 7781

E-ISSN 2615 - 3238

2. Deployment diagram

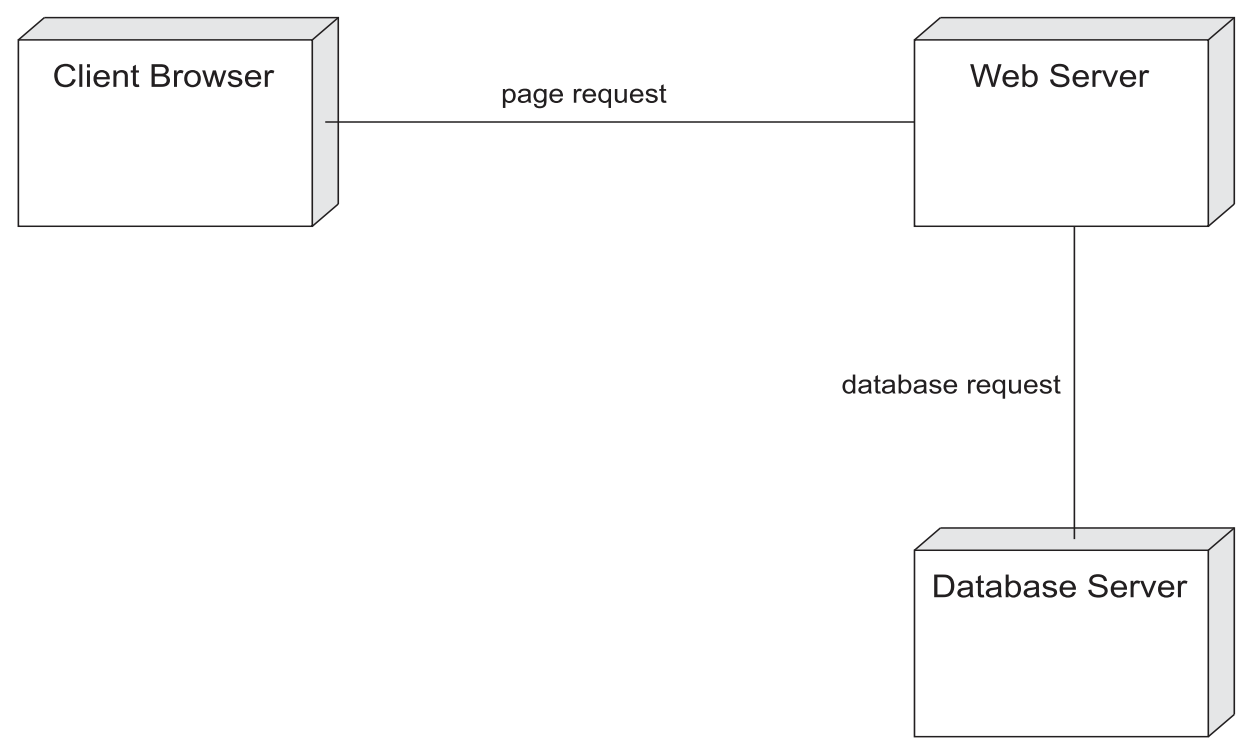

Gambar 18: Deployment diagram

\section{Pengkodean}

Menurut Sukamto yang merupakan praktisi dan akademisi di bidang perangkat lunak, Desain harus ditranslasikan ke dalam program perangkat lunak. Hasil dari tahap ini adalah program komputer sesuai dengan desain yang telah dibuat pada tahap desain(Walim \& Hidayatun, 2018).

3. Pengujian dengan menggunakan Black Box

Sering disebut juga glass-box testing, merupakan metode testing yang menggunakan kontrol struktur dari rancangan prosedural untuk melakukan test case dan mengetahui internal dari website.Design test dijalankan pada semua internal dari website untuk memastikan mereka beroperasi berdasarkan spesifikasi dan design. 
P-ISSN 2580 - 7781

E-ISSN 2615 - 3238

Tabel 3: Uji Black Book

\begin{tabular}{|l|l|l|l|l|l|}
\hline No & $\begin{array}{l}\text { Skenario } \\
\text { pengujian }\end{array}$ & $\begin{array}{l}\text { Test } \\
\text { case }\end{array}$ & $\begin{array}{l}\text { Hasil yang } \\
\text { diharapkan }\end{array}$ & $\begin{array}{l}\text { Hasil } \\
\text { pengujian }\end{array}$ & Kesimpulan \\
\hline 1. & $\begin{array}{l}\text { Klik data } \\
\text { penjualan }\end{array}$ & $\begin{array}{l}\text { Link } \\
\text { data } \\
\text { penjual } \\
\text { an }\end{array}$ & $\begin{array}{l}\text { Muncul data } \\
\text { pembelian }\end{array}$ & $\begin{array}{l}\text { Sesuai } \\
\text { harapan }\end{array}$ & Valid \\
\hline 2. & Klik hapus & $\begin{array}{l}\text { Link } \\
\text { hapus }\end{array}$ & $\begin{array}{l}\text { Sistem akan } \\
\text { menghapus data }\end{array}$ & $\begin{array}{l}\text { Sesuai } \\
\text { harapan }\end{array}$ & Valid \\
\hline
\end{tabular}

\section{KESIMPULAN}

Berdasarkan hasil pemograman dan pengolahan data yang telah dilakukan, penelitian ini menghasilkan sebuah aplikasi website yang dapat digunakan sebagai sarana promosi dan transaksi. Beberapa kesimpulan dari website ini yang penulis buat adalah :

1. Website yang penulis buat merupakan sarana untuk mempromosikan dan juga untuk bertransaksi secara mudah dalam hak akses yang lebih luas kepada masyarakat.

2. Website ini mempermudah pengunjung dalam melihat produk dan mencari informasi tentang produk yang di inginkannya khususnya produk yang ada pada Toko Hardware online.

3. Dengan adanya website ini memperluas pemasaran produk hardware karena dapat diakses transaksi online kapan saja dan dimana saja.

\section{SARAN}

Seluruh program, fungsi, struktur dan content yang tersedia dalam pembuatan aplikasi website ini masih belum dapat dalam tahap sempurna, seiring dengan alasan tersebut maka TOKO HARDWARE ONLINEselalu mencari sesuatuyang baru agar dapat terus berinovasidalam mengembangkan aplikasi berbasis web ini. 
P-ISSN 2580 - 7781

E-ISSN 2615 - 3238

Dengan mempertimbangkan keadaan sistem yang buat kurang maksimal maka terdapat beberapa hal yang perlu dikembangkan demi menjaga aplikasi ini dalam jangka panjang, berikut adalah pengembangan yang dapat dilakukan dalam aplikasi berbasis web:

1. Diharapkan administator dapat turun serta dalam pengelolaan data secara berkala dan rutin akan menghasilkan informasi yang up to date.

2. Kemudahan dalam penjelajahan situs perlu diperhatikan agar pengunjung dapat menerima informasi dengan mudah.

3. Diharapkan banyak sekali diskon-diskon pada website ini bukan hanya pada hari tertentu saja.

4. punyai back up file yang lengkap.

5. Diharapkan bisa di hosting.

\section{DAFTAR PUSTAKA}

Ardhana, K. (2012). Dengan PHP: Membuat Website 30 Juta Rupiah. Jakarta: Jasakom.

Gata, W., Basri, H., Puspitawati, D. A., \& Hidayat, S. (2019). Implementation of Decision Tree Algorithm in Customer Recency, Frequency, Monetary, and Cost Profiling: a Case Study of Plastic Packing Industry. IOP Conference Series: Materials Science and Engineering, 662(2), 22032. IOP Publishing.

Nazir, M. (2011). Metode Penelitian. Bogor: Ghalia Indonesia.

Shalahuddin, M. (n.d.). Rosa. 2015. Rekayasa Perangkat Lunak Tersruktur Dan Berorientasi Objek. Bandung: Informatika.

Sugiyono, H. (2016). Metode kualitatif dan kuantitatif. Cetakan Ke-23. Alfabeta, Bandung.

Suhardi. (2019). PENGARUH GAYA HIDUP, DEMOGRAFI DAN KUALITAS PRODUK TERHADAP KEPUTUSAN PEMBELIAN KONSUMEN. PERSPEKTIF, 17(1), 93-103.

Suhardi, S., Widyastuti, T., Bisri, B., \& Prabowo, W. (2019). FORECASTING ANALYSIS OF NEW STUDENTS ACCEPTANCE USING TIME SERIES FORECASTING METHOD. Jurnal Akrab Juara, 4(5), 10-23.

Sukamto, R. A., \& Shalahuddin, M. (2014). REKAYA PERANGKAT LUNAK TERSTRUKTUR DAN BERORIENTASI OBJEK (2nd ed.). Bandung: Informatika.

Sukatmi, S. (2018). Aplikasi Presensi Siswa Berbasis Web dengan Dukungan SMS Gateway pada Smk Kridawisata. Jurnal Cendikia, $16(1$ April), 29- 
P-ISSN $2580-7781$

E-ISSN 2615 - 3238

34.

Susandi, D., \& Sukisno, S. (2017). Sistem Penjualan Berbasis E-Commerce Menggunakan Metode Objek Oriented pada Distro Dlapak Street Wear. JSiI (Jurnal Sistem Informasi), 4.

Suwarna. (2008). Cara Membuat Tabel Dengan Logical Record Structure (LRS). Bandung: Gramedia Bandung.

Talika, F. T. (2016). Manfaat Internet Sebagai Media Komunikasi Bagi Remaja. Acta Diurna, 5(1), 2.

Walim, \& Hidayatun, N. (2018). Rancang Bangun Aplikasi Sistem Informasi Pemesanan Dan Penjualan Daging Burung. Journal Speed - Sentra Penelitian Engineering Dan Edukasi, 10(3), 29-33.

Widyastuti, T., Bisri, B., \& Suhardi, S. (2020). PERILAKU ASERTIF DALAM MENINGKATKAN PRESTASI KERJA KONSULTAN MULTI LEVEL MARKETING. CERMIN: Jurnal Penelitian, 4(1), 188-201.

Yuhefizar, H. A. (10AD). Jam menguasai internet teknologi dan aplikasi. Jakarta: Elex Media Komputindo. 